\title{
Are Reasons Enough? Sen and Ricoeur on the Idea of Impartiality
}

TODD S. MEI University of Dundee

With respect to distributive justice, controversies over the sufficiency of a conception of impartiality generally involve the problem of how a standard of rational justification ignores features, values, or attributes of individuals or groups placed under scrutiny. This problem of justification has often been referred to as the adoption of "monological" moral reasoning which, as Seyla Benhabib puts it, "proceeds from the standpoint of the rational person, defined in such a way that differences among concrete selves become quite irrelevant." 1 The stronger contention derived from this criticism is that a theory of impartiality is impossible since it must assume some rational principles which will inevitably exclude diverse others. ${ }^{2}$

Amartya Sen offers a comparative account of impartiality in which difference and individual perspective are taken seriously. Throughout Sen's analysis it is clear that he relies on epistemological criteria to justify certain procedures while discounting others, or what Elizabeth Anderson refers to as an "epistemological strategy for dealing with the multiplicity of evaluative perspectives." ${ }^{3}$ At the same time, this account is, as Anderson notes, "pragmatic" with respect to finding resolution by removing the most agent-relative reasons through a process of critical scrutiny that employs trans-positional objectivity and an open impartial observer. ${ }^{4}$ (I will explain these concepts later.) However, while Sen makes the argument that his theory avoids any kind of monological reduction or universalization of rational principles, there is a problem concerning the role of socially 
and historically determined normative values ${ }^{5}$ and how Sen expects that a process of critical scrutiny will weed out unreasonable values, claims, and principles in order to arrive at "shared reasons." 6

Beyond his reference to normative concepts and diversity of influences gleaned from sociological analysis, ${ }^{7}$ there is a lacuna in which Sen leaves underdeveloped a treatment of 'non-rational' beliefs determining our behaviour and ethical reasoning. I use the word non-rational to reflect factors whose efficacy in shaping our ethical reasoning needs to be taken into account, yet in such a way that we should not expect these to conform to the remit of conventional standards of what it means to be rational or have adequate justification. ${ }^{8}$ Such beliefs are not irrational but, as I will argue, in large part constitute our human understanding since they are substantive ethical beliefs which we inherit by virtue of the historical and cultural transmission of knowledge, or those beliefs which are 'prejudices' according to the original, non-pejorative meaning of the word. ${ }^{9}$ Following Paul Ricoeur, I will discuss these beliefs more specifically in terms of 'ethical convictions' (hereafter shortened to 'convictions').

This strategy is by no means trivial. As I will show, there is more to the kinds of convictions of which Ricoeur speaks than meets the eye. They are not just beliefs that favor partiality or care towards oneself or a member of one's group. Rather, they form part of the bedrock on an entire ethical order ${ }^{10}$ in which meanings and values are ascribed not only to others but to what is ultimately at stake in one's existenceeschatological, political, or otherwise. To be sure, philosophers often pay attention to such orders, particularly with reference to religious conflict (either with other religions or with secularism). However, part of what Ricoeur understands by the term ethical order, 
and which I will explain in more detail later, is how convictions within an order are largely if not totally incommensurable with other orders. ${ }^{11}$ This does not mean that the one who holds convictions is incorrigibly stubborn. Rather, it is to suggest that the order in which one's values emerge is largely untranslatable into another order, especially one which attempts to enact an impartial form of mediation. In this respect, it is worthwhile noting that much of the analytic literature discussing debates between impartiality and partiality tacitly assume that different discourses and languages respective to competing groups are to a large degree unproblematically inter-translatable. ${ }^{12}$ Or if the literature does not make this assumption, then clarification of meaning is seen to be one of the virtues and results of a process of public reasoning, coordination, or progression to more sufficient types of justice. ${ }^{13}$ So, bringing Sen and Ricoeur into dialogue with one another offers a way of introducing and rethinking "the fact of pluralism" not simply in terms of competing values, allegiances, or moral requirements but of recognizing how such conflicts involve convictions (and therefore ethical orders) that make translation significantly problematic.

My thesis on Sen is that his theory of impartiality is incomplete insofar as he maintains that critical scrutiny from various points of view can sufficiently secure impartial judgement. Sen, I will argue, does not adequately develop a role for convictions, relying too heavily on the critical role of reason as a means of stemming and even correcting convictions. Can one accurately distil convictions into reasons given different cultural and historical traditions that inform the understandings of others?

While this is a problem concerning the adequacy of Sen's theoretical account, it has a significant practical implication. If convictions constitute a substantial foundation 
for ethical reasoning, then shared reasons gained through a procedure of impartial mediation will not fully address or resolve the stronger motivations of an individual or group holding a conflicting view. In other words, one might agree to reasons, but this agreement may be superficial, even with the best intentions to attain consensus or reconciliation. As we will see, convictions are not readily revisable in view of shared reasons, and this is because they involve substantial commitments to an interpretation of how existence should be lived according to inherited ethical norms whose authority has been legitimated as a result of a group's historically constituted identity. In many cases, especially in serious instances of cultural conflict, one is not merely faced with the task of finding shared reasons but reinterpreting centuries of a tradition of understanding and practices. ${ }^{14}$

Ricoeur's theory of impartiality, on the other hand, provides both a strong contrast to criticize Sen and an alternative to the resolution of conflicts within the domain of distributive justice. In short, there are two significant differences that should be noted. First, Ricoeur anchors impartiality not to a notion of objectivity but a willingness towards mutuality. He sees impartiality as a broad ethical concept that is defined, motivated, and justified by one's own moral tradition. Impartiality, in other words, presupposes a normative commitment to be responsible towards and respectful of 'an other.' Second, Ricoeur maintains that prior to reasons are convictions. If the roots of convictions run deep in how we form and assess fair procedures for resolution, then we require a conception of impartiality that does not simply attempt to bracket them out. Instead, impartiality is possible only after the conflicting parties have understood each other's convictions. This entails not looking for reasons upon which they can 
agree, but making the attempt to become familiar with the history and cultural nuances of the other person's tradition and, as mentioned earlier, ethical order. As we will see, the attempt to understand another's ethical order differs from Sen's appeal to positional objectivity. But for now it is necessary only to mark that Ricoeur's approach offers a distinct advantage; namely, it does not attempt to redescribe convictions as that which are opposed to reason but instead as a major component of our rationalising process. This not only claims a more realistic account of conflict but, as importantly for Ricoeur, it places distributive justice within a project of mutuality as opposed to agreement.

There is one qualification to note about my analysis of Ricoeur's conception of impartiality. Ricoeur often speaks of impartiality in relation to corrective justice and legal systems. I therefore take some liberty in interpreting how impartiality relates to the distinct field of distributive justice. My claim is that this maneuver is not far-fetched if one bears in mind that while corrective and distributive justice both use impartiality to establish a "just distance" in which testimony can be heard, the latter is distinct in its search for mutual understanding. ${ }^{15}$

This essay is divided into four sections: I will provide an analysis of I) Sen's account of open impartiality and how it avoids the charge of universalization; II) how Sen's theory remains incomplete when assuming that reasons are sufficient in mediating conflict; III) Ricoeur's conception of conviction; and IV) Ricoeur's theory of impartiality and how it involves the aim of mutuality.

\section{Recapitulating Sen}


For Sen, distributive justice is in large part secured by open impartiality which is a participatory process that moves towards 'better reasoning' by exposing to critical scrutiny the rational principles which inform our commitments, choices, and value judgements. ${ }^{16}$ The decisive part of this process is how open impartiality involves the employment of a global dimension of evaluation where reasons derived from different perspectives can be tested for justification beyond the consideration of the groups and institutions immediately involved, or what Sen calls "focal groups."17 Because Sen takes the role of different perspectives seriously, he is sceptical of theories of justice predicated on a conception of universality, that is, when a theory is founded on or presupposes a uniformity of principles upon which we can all agree. Sen is also critical of such theories insofar as he deems the role of universality as unnecessary and insufficient for a theory of justice. ${ }^{18} \mathrm{He}$ argues instead that agreement does not arise by applying an ideal standard of rational justification or set of putative universal principles, but is achieved by virtue of the participants working out their disagreements and ideally finding reasons they can share. ${ }^{19}$ Anderson describes this as a "learning" process of reason that can help to achieve a "superior evaluative perspective."20

Sen is careful when explaining exactly how this alternative is theoretically and practically viable. I will summarize his account according to three stages: 1) positional objectivity; 2) trans-positional objectivity; and 3) open impartiality.

First, Sen acknowledges that positionality is inescapable and significant in the formation of values and relations to things and others; an account of perspective needs to be included when attempting to understand the value judgements of a person. Sen uses the concept of positional objectivity to explain how objectivity is present in 
individual perspective: What each perspective entails is a view of reality whose objectivity can be confirmed if "such an observation could be reproduced by others if placed in the same position." ${ }^{21}$ Thus positional objectivity is "the objectivity of what can be observed from a specific position" by anyone. ${ }^{22}$ In this respect, Sen departs from the traditional epistemological notion of objectivity that does not require the inclusion of individual perspective in striving for interpersonal invariance.

Second, because something can be viewed from many different perspectives, there is a need to include a variety of positionally objective perspectives. Sen observes that positional objectivity from several positions is therefore "not so much a 'view from nowhere,' but a 'view of no one in particular'."23 The collection of positionally objective views is what he refers to as a "trans-positional" form of assessment. "The constructed 'view from nowhere' would then be based on synthesizing different views from distinct positions."24 Trans-positional assessment forces a heavier justificatory burden on evaluation since we are asked to form a coherent view from the different positions.

Third, Sen makes clear that trans-positionality does not refer to a viewpoint alien to the immediate context of focal groups. Because of this, there is a caveat to transpositional objectivity insofar as the various positions within a focal group can fall prey to "systematic illusions," like the flatness of the earth, and "persistent misunderstandings," like the inferiority of women. ${ }^{25}$ What can arise from these illusions is a sense of impartiality that is fair when it is actually limited by agent-relative beliefs or misinformation. Sen refers to this as a "closed" impartiality which has three traits: "Procedural parochialism" (shared prejudices of the focal group), "Inclusionary incoherence" (exclusion of others by the criterion of the internal consistency of focal 
beliefs), and "Exclusionary neglect" (neglect of others outside the focal group and affected by decisions). ${ }^{26}$ So what becomes prudent for Sen is to include an open and impartial perspective alien to the trans-positional group.

Sen's claim is that open impartiality facilitates the process by which the reasons of competing parties can be rationally scrutinised and the process of fairness can be optimised. ${ }^{27}$ Through an open, impartial observer values can be compared and assessed in order to identify unreasonable biases lurking under the veil of positional and trans-positional objectivity. ${ }^{28}$ Sen's comparative theory attempts to secure objectivity by placing the claims in question in dialogue with an observer outside the immediate debate. ${ }^{29}$ As a whole, this process forces a comparative form of assessment whose aim is the distillation of general reasons to produce impartial reasons, or "what others cannot reasonably reject." ${ }^{30}$ Moreover, this comparative process is not simply formal in the sense that it provides steps to be taken; rather, it is the instantiation of reason itself since in illuminating impartial reasons, it requires of us to explain such reasons in a way that others can follow.

While Sen's theory admits some features of universalized conceptions of impartiality that rely on the ability "to represent the theoretically relevant interests of all involved persons," ${ }^{31}$ he refrains from the temptation of universal truth claims and the traps of stringent epistemic and cognitive requisites by reducing the remit of impartial assessments to specific situations. The role of impartiality is, above all, only situationally directed; what arises from the mediation by impartiality is never anything like the result of submitting one's maxim to the test of the rule of universalization. ${ }^{32}$ Instead, differences hope to be settled by consensus; and this conclusion in itself means very 
little to the establishment of universal values and precepts for the whole of the global community. ${ }^{33}$ Impartiality exposes the sufficiency of reasons which at best become shared reasons amongst diverse groups with respect to a specific conflict $^{34}$ and therefore is concerned with "actual freedoms," that is, the freedom an individual has in order to pursue his or her ends and the capability to achieve those ends. ${ }^{35}$

Having said this, is there still a way to reassert the charge of universalism against Sen? One might allege that despite the inclusion of the third, impartial observer, procedures of reasoned scrutiny cannot but help impose some standard of justification that would misrepresent one of the parties' beliefs. A reply to this charge lies in showing its unreasonableness. The danger of arguing from a robust notion of pluralism, or an ideology of difference, is that it forces a continual retreat from resolute judgement by forever protecting individual identity against others. As a proponent of much of Sen's philosophy, Anderson has clarified how theories critical of impartiality misunderstand the pragmatics of public debate if they think preservation of individual identity is the most significant aim. Ricoeur shares this criticism when noting how "[t]he paradox is indeed that the praise of difference ends up reinforcing the internal identities of the groups themselves." ${ }^{36}$ Anderson concludes that what is of most importance is that individual claims are not seeking "validation of their parochial positionality as particular, but to offer up their perspective as universal, as properly shared by all." ${ }^{37}$ It is the supposition of universality which lends itself to genuine debate. But while assuming universality to be an integral motivation for debate, Sen's situationally based, comparative approach does not assume that a process of debate will reach the establishment of universal principles. In any situation concerning conflict over reasons, one need only attend to the 
debate at hand without concern for an overarching doctrine of what constitutes justice or reason. ${ }^{38}$ Commitments to open impartiality, as long as they are identified by each party, enable a particular debate to follow the process of scrutiny more successfully and therefore articulate and represent respective identities.

Nevertheless, one can still persist in criticising Sen's approach. While practical, Sen's attempt to mute universal claims through a comparative approach leave the role of convictions unaddressed. Even if the comparative process is not interested in establishing universals, the people engaged in debate often are, or at the very least, see any substance of their claims as correlative to their universality. The problem with Sen is not the marginalization of diverse identities, but rather, his assumption that shared reasons are adequate for providing understanding in situations of conflict.

\section{Incompleteness of Sen's Account}

The critical reading of open impartiality that I will be providing in this section relates to Sen's account of rational debate as the process by which the diversity of values informing a person's rationality can be translated into reasons through the use of critical scrutiny in public, reasoned debate. While his efforts have transformed the way in which economics approaches rational behaviour, my intent is to push his account further by maintaining that given the diversity of normative values, some of these values are not easily or readily translated into reasons that would have a wide public acceptability. Indeed, in cases where there tends to be a significant level of disagreement, the problem of understanding the meaning of unfamiliar concepts and practices appears the fundamental obstacle..$^{39}$ 
In his critical analyses of maximizing behaviour, ${ }^{40}$ Sen acknowledges the legitimacy of normative values as influences on volitional choice-making. He rightly broadens a conception of rationality and how rational agents may be acting from convictions, precepts, or principles beyond self-interest or utility maximization. Sen therefore leaves the category of "normative" broad since he is content to accept it as something which is, despite whatever specific content it may have, complex and therefore not easily decipherable. He argues that it is the task of evaluative theory employed by economists to recognize the variety of normative values and be able to accommodate them in their explanatory and predictive models. ${ }^{41}$ For instance, looking at the theory of "revealed preference" in economics, where a preference is presumed from a choice taken by an agent, ${ }^{42}$ Sen refers to the complexion of normative influences under the term "social":

$[\mathrm{M}]$ an is a social animal and his choices are not rigidly bound to his own preferences only.... An act of choice for this social animal is, in a fundamental sense, always a social act. He may be only dimly aware of the immense problems of interdependence [of "different people's choices"] that characterize a society. . . [b]ut his behaviour is something more than a mere translation of his personal preferences. ${ }^{43}$

"Social" in one sense can be defined as the relations and practices that generate what one believes to be ethical precepts consistent with the group with which one identifies. ${ }^{44}$ 
Indeed, an agent's choice does not always reveal his or her preference, and there may be other normative commitments involved.

In order to make his account more accommodating to the mire of competing normative claims, Sen relaxes some of the criteria traditionally seen to constitute rationality—such as internal consistency and completeness of rankings. In addition, he acknowledges that the interpretation of language is a perpetual obstacle; this includes not only languages foreign or unfamiliar to a focal group but also, as Sen points out, diverse "language games" in which even the same language can involve different meanings, connotations and especially "social elements" which serve to create an impasse to communication. ${ }^{45}$

Nonetheless, despite these concessions, there is an assumption in Sen's argument that in the arena of debate, normative values and claims can be translated into reasons that are more or less accurate in representing and justifying others' points of view. He refers to this at one point as

the extensive use we make of rationality in understanding what others are doing and why, and also what they know, what we can learn from what they know, and so on. ${ }^{46}$

As Sen explains, this process is "foundationally connected with bringing our choices into conformity with critical investigation of the reasons for that choice." 47 My contention is that he takes an overly pragmatic view to the resolution of conflicts. Instead of persisting with the uniqueness of discourses and language games, Sen maintains that the process 
of reasoned debate requires conflicting parties to express their "non-conformist proposals" through "conformist rules." 48 This assumes that an articulation of beliefs according to existing rules is not significantly problematic. ${ }^{49}$ But there are at least two reasons as to why we should think otherwise. First, conformist rules and the concepts employed by these rules are taken to be adequate in representing a person's point of view and the tradition to which he or she attaches meaning. Second, Sen assumes that people involved in reasoned debate understand the rules and concepts presented to them and the authority the rules have in governing the debate. As we will see later, for Ricoeur the project of translation ought to include the attempt to understand an ethical order from within its own system and concepts. This provides not only a more sufficient means of understanding the claims of another, but it can also provide a critical function for an existing institution or focal group by contrasting a convention with what would be normally viewed as unfamiliar or even prohibited. ${ }^{50}$ Sen's approach assumes that this critical function can still retain its integrity when another's claims are translated by "conformist rules."

A concrete instance of the problem of translatability, and one relating directly to claims of distributive justice, is the conceptualization of land as an economic factor of production. Especially, since the marginal revolution of the $1870 \mathrm{~s}$, it is now commonplace to assume land is not a distinct factor of production; it is either subsumable under labor (as with Marx) or capital (as Pareto declared). ${ }^{52}$ The loss of this classical distinction arguably endorses a legal conception of landownership that allows land to be exclusive, private property since it is not seen as something ontologically distinct and therefore requiring special treatment or definition. For example, opposed to 
the idea of exclusive, private property in land is the notion of possession of land by usufruct-that is to say, one retains legal possession of land only insofar as he or she is using it for production or to live. There are, of course, many reasons one can cite in favor of and against usufruct. Such debates originated with the classical economists (i.e., Smith, Malthus, and Ricardo) and continue to this day with respect to a neutral land value tax. ${ }^{53}$ My point here is that despite the wealth of reasons for possession of land by usufruct, there may be underlying normative values that act as substantive meanings for why someone might insist that there can be no such thing as exclusive, private property in land. Native North Americans, the True Levellers, and supporters of Henry George share this idea but have, nonetheless, different ethical orders underwriting their convictions. ${ }^{54}$ Is it enough in these instances to rely merely upon reasons in conformity to existing rules of a focal group?

It seems difficult to say "yes." By digging deeper into meanings, values, and concepts, one begins to understand more fully how and why a position is taken, and what may in fact result is a view through which the predominant focal group's practices can be revised..$^{55}$ To see the expediency and sufficiency of a land value tax that is often paired with usufruct, in other words, is not the same thing as seeing why exclusive claims to land are ethically prohibited. To allow this misunderstanding to persist is not only to misunderstand the distinctness of ethical goods versus economic ones, but also to ignore the kind of practices and ends that inform one type of goods compared to the other. To maintain the distinction in choosing ethical goods, on the other hand, allows the ethical force of something like a land value tax policy to be apprehended as a form of ethical practice (and not simply a value-neutral or even optimal policy). Moreover, it 
helps one make sense of our own historical traditions-i.e., the classical period of political economy, where one finds other ethical norms underwriting, for example, Adam Smith's decision to uphold landownership despite the just nature of a land tax. ${ }^{56}$

Returning to issues concerning rules of debate and translatability, there is the problem of Sen's conception of rational discussion which seems to ignore contingent features involved in the endeavour to achieve successful communication. In procedures of debate where convictions are no longer legitimate and where the only things admissible are reasons, actors within a debate can tend towards a compromise of their own beliefs in view of a possible remedy to a conflict. This often happens in everyday circumstances where one person will translate another person's thoughts ("Is what you mean this ... ?"). The other person often consents in the interest of moving the discussion forward, not realising until later that the terms have shifted the focus and potential outcomes of the debate. Such shifts, as Hagi Kenaan points out, create distinct standards of successful reasoning in communication, standards which exclude a "middle ground" where meaning is only inchoately understood because it is difficult to articulate in another way. ${ }^{57}$ It seems likely that Sen can only view the establishment of such standards as a process of moving towards better reasoning.

In view of these contentions, it is questionable whether Sen accounts for "other people" sufficiently. Indeed, he mentions only how rational agents need to take into account other people beyond the narrow description of agency as self-maximizing. ${ }^{58}$ Within Sen's development of "commitment," relation to others, even if altruistic, is a relation to their welfare and not necessarily their beliefs. This formulation is overly narrow since it does not require an adequate understanding of another. ${ }^{59}$ So while Sen 
may be sympathetic to identifying normative values when theorizing about them, I think there is a pressure on him to do more. Reasons, in other words, only scratch the surface of what is happening in conflicts of distributive justice.

\section{Ricoeur on Convictions}

Ricoeur develops his account of convictions according to an epistemological distinction he finds not only more realistic in view of everyday conflicts but productive when understood in a broader framework. Because theories about argumentation like Sen's often focus on separating forms of "bad reasoning" from forms of "better reasoning," there is a correlative tendency to view beliefs like convictions as those things which need to be discarded if they lack a certain standard of justification. When understood as beliefs lacking reasoned self-scrutiny, convictions occupy the place of parochial reasoning that Sen describes. Contrary to this, Ricoeur insists that convictions express a form of commitment to values and meanings whose normative content has authority for a focal group yet remains to be worked out and justified practically, that is, according to emergent situations of conflict. Convictions, as he will say, are therefore always "considered convictions," 60 that is, beliefs that express a universal claim but are inchoately justified because they have yet to be applied and worked out according to real situations.

For Ricoeur there is no epistemological foundation for convictions if what is meant by foundation is a self-secured and certain beginning. Convictions are ethical beliefs that arise from within the context of an already existing ethical order or system of values. ${ }^{61}$ As he qualifies, convictions are not 'beliefs that' but 'beliefs in'; exactly that to 
which the 'in' refers involves already existing values one has inherited through history and tradition. ${ }^{62}$ So, in this respect, one has a belief in one's capacity to make decisions by virtue of an existing order of ethical values. As 'convicted,' I am convinced a decision made is 'good' according to the context of my ethical values. Convictions are truly normative in the sense that they are possible only because an ethical order provides a "totality of signification" in which one can distinguish between good and bad actions. ${ }^{63}$ Ricoeur, like Alasdair Maclntyre, describes this feature of knowing and decision-making in terms of order, that is, an order of some kind that precedes each of us and is often recognizable as a tradition of practices and shared understanding:

The term "order" conceals the greatest difficulty for ethico-juridical philosophy, namely, the status of the authority attached to this [...] order, that which even makes it an order. ${ }^{64}$

We recognize ethical orders according to the way in which we recognize what has authority over our decision-making. Thus, to reason one's way to a judgement about a choice requires the values, given by and accepted on authority, in order to delineate a good choice from a bad one. Ricoeur's fundamental point is to show that within the ethical domain, our reasons for acting in one way and not another are not reasons in the fully choate form of being justified. Rather, they are convictions that arise from within an ethical order which we are then brought to justify in situations of conflict.

In other words, convictions act as criteria for what an agent believes to be the basis for a prudent choice. These criteria are not identical to justifications: In situations 
of moral conflict, rational agents make decisions concerning how to act as if they were anticipating a requirement of justification. Criteria can then be employed in the task of justifying an action should the agent be held accountable by someone else, an institution, or even the agent him- or herself. The criteria provided by an ethical order enable an agent to believe (to be convinced) that what he or she is doing is good, right, or prudent. But the move from relying on criteria for justification presupposes the language in which justificatory statements are made is either unproblematic or transparent in meaning. And this, as we will see in the final section, is precisely that with which Ricoeur takes issue. But for now, let us note how Ricoeur emphasizes that convictions are beliefs that enable one to act ("I can"), whereas Sen holds a weaker standard for responsible agency insofar as we need only make causal connections between our choices and possible outcomes. ${ }^{65}$ And this standard is perhaps presupposed by his assumption that shared reasons can be rather easily and practically ascertained.

Nonetheless, a critic of Ricoeur might argue that the relation of convictions to justification is viciously circular, epistemologically and ideologically. If we do not appeal to anything beyond convictions, whatever we argue will simply presuppose those convictions. Ricoeur's counter is that any circularity between convictions and justification entails a process of critical revision wherein the demand for justification becomes a way of revising one's convictions from within his or her ethical order.

Epistemologically speaking, Ricoeur understands ethical reasoning as a reasoning "aware of its own lack of foundation" 66 and therefore seeking to justify actions through a process of argumentation within one's own tradition. Because convictions lack 
certainty (e.g., I am convinced of something but not certain of it), their validation arises through argumentation with others who do not agree. Such challenges put an ethical order under strain to respond reflectively. Similar to Maclntyre's notion of internal revision of a tradition through rival conflict, Ricoeur emphasizes that any revision is not one in which another order imposes itself. Rather, external pressure allows for a refiguration of existing beliefs and values. ${ }^{67}$ Furthermore, Ricoeur grants that this process of argumentation articulates universal claims with the caveat that no justification can ever completely secure a claim's universality. So while "No moral conviction would have any force if it did not make a claim to universality," at the same time for Ricoeur, a conviction is "an alleged or inchoative universal seeking recognition." 68 The process of seeking recognition is a process of validation through argumentation whose conclusion attests to a universal principle of some kind that itself is subject to further validation according to new situations that arise, or what is a process of verification throughout one's whole life ${ }^{69}$ Ricoeur thus sees the paradigmatic model of argument and validation as being "the juridical procedures of legal interpretation" which always hold in view a law in relation to a specific context. ${ }^{70}$ It is worth recalling that Sen sees public debate as a practical, comparative remedy without universal implications. Ricoeur, alternatively, reads the tension between universal claims and historical/situational conflict as a dialectical structure through which universal claims can gain more coherency, especially through their revision. ${ }^{71}$

In terms of social praxis and the critique of ideology, Ricoeur does not see the circular relation between convictions and justification as a form of domination as does, for example, Pierre Bourdieu when analyzing the relation between habitus and modes 
of production. ${ }^{72}$ Rather, for Ricoeur, because ethical reasoning is often faced with conflicts in specific situations, it forces the reasoning of focal groups to reassess their own assumptions and customs. There is no guarantee that this self-critical scrutiny will emerge; and critics may charge that a conception of ethical reasoning which does not more strongly force self-scrutiny is to a large degree inadequate. However, Ricoeur insists that genuine argumentation in the arena of distributive justice and ethics requires an appropriate hospitableness which cannot be forced. He refers to this as an inchoate mutuality in which parties are willing to receive each other. At the same time, he is not saying that procedures of justice which require debate and arbitration should be expunged, only that while such procedures may be in place and enforced, they cannot guarantee genuine debate since this requires both parties to be willing to recognize and respect each other. ${ }^{73}$

Ricoeur refers to this generally as a "linguistic hospitality," noting that the conflicts of distributive justice usually involve conflict at the level of diverse languages; even when parties speak the same language, as Sen too recognizes, different conceptual connotations, customs, and normative meanings can be hidden. Thus, the normativity of different languages requires a translation process between parties. However, unlike Sen, Ricoeur emphasizes the notion of hospitality: Translation between parties is not possible unless a certain amount of charity is granted to the other as expressing a rational and coherent view, which includes and does not omit their convictions:

This phenomenon of linguistic hospitality can serve as a model for all instances of understanding in which the absence of what we might call a 
third-person overview brings into play the same operations of transference and of welcome whose model can be found in the act of translation. ${ }^{74}$

When referring to the "third-person overview," Ricoeur is not suggesting like Sen that a third impartial observer would help to remedy conflict. Rather, he is suggesting here that its absence is a fact; a third-person overview is not possible because for the third person to be entirely impartial, a neutral metalanguage would be required to translate the points of view of both sides equitably. Elsewhere Ricoeur comments,

The path of eventual consensus can emerge only from mutual recognition on the level of acceptability, that is, by admitting a possible truth, admitting proposals of meaning that are at first foreign to us. ${ }^{75}$

In short, it is the distance in communication separating individuals and groups that provides for a genuine mutuality; genuine because communication must be 'won' through understanding a position foreign to one's own. It is the role of impartiality, as we will see, to ensure this distance is productive.

It is true that Ricoeur places a great deal of trust in an individual's capacity to admit another according to a linguistic hospitality, but because convictions are themselves never certain forms of knowing, they should be understood to involve a mode of communication which does not stake itself upon a claim to finality. Ricoeur therefore speaks of this component of his theory of justice as an "act of confidence" in 
our capacity to admit the other person into debate, without which claims to social cooperation and flourishing would be empty or an act of bad faith. ${ }^{76}$

\section{Ricoeur on Impartiality}

So far, I have presented Ricoeur's account of convictions as that which positively and substantially underwrites a group's claims within the domain of distributive justice. But, then, does not the normative and therefore prejudicial nature of convictions make impartiality impossible? In this final section, I will discuss how Ricoeur is able to retain impartiality despite the prevalence he gives to convictions and, moreover, that his account of impartiality is more convincing than Sen's. Seeing how Ricoeur links convictions to impartial judgement requires a significant shift in assuming what impartiality is. On Sen's account, impartiality provides an objective standpoint built on shared reasons. But for Ricoeur, since objectivity is impossible, impartiality is more accurately an inter-subjective standpoint potentially providing a "shared understanding." ${ }^{\text {"W }}$ Where Sen wants a viewpoint "from nowhere in particular," Ricoeur desires a more hospitable engagement.

To see the contrast between the two in more detail, let us begin with a point on which they agree: Impartiality requires the ability of one group to place itself in the other's position. Recall that for Sen, occupying the position of another has as its aim the delineation of objective reasons that anyone occupying that position cannot reject. For Ricoeur, however, the role of placing oneself in another's position presupposes some degree of a mutuality of understanding. How can one genuinely attempt to occupy another's position without admitting in some way the convictions of this other person? 
Finding reasons cannot do this work since there are often concepts foreign to one's perspective that cannot be easily distilled into reasons that can be shared. Indeed, Ricoeur's distrust of shared reasons stems largely from his understanding of the complexity of religious traditions and the distinct and separate discourses-or language games-they involve. ${ }^{78}$

But if the turn to objectivity is not possible, and if Ricoeur wishes to retain impartiality as a fundamental feature of debate, he has but one viable option: $\mathrm{He}$ maintains that a conception of impartiality is itself normative. In other words, the need to engage with another impartially is itself an ethical good esteemed within one's own ethical order. But this claim is not simply a reduction of impartiality to a normative framework. Ricoeur's strategy is to show how the normative framework enables one to transcend parochial limitations by virtue of the burden placed on oneself by the demand for impartiality articulated in one's ethical order. The ethical demand to be impartial is exceptionally other-regarding. ${ }^{79}$ As we will see below, as such it often identifies exceptions to the norm according to which convictions can be revised. Ricoeur summarises this exceptional nature as "the concept of impartiality" placed at "the summit of the ethical life." 80

Ricoeur observes that impartiality is possible because one can impute oneself as responsible for being impartial. To impute oneself-that is, to take account of oneselfinvolves a self-reflexivity presupposed by the demand to be impartial. Without "the capacity of a subject to designate itself, himself, or herself as the actual author of its, his, or her own acts," that is, "the capacity to posit oneself as an agent," 81 one would lack the ability to recognize those situations of conflict in which one ought to strive for 
impartiality. Indeed, without this capacity, Sen's explanatory account of the causal connection between a choice and its consequence does not seem sufficient unless it can be shown that this type of causal connection is innately and substantially otherregarding, and not simply concerned about the other's welfare. ${ }^{82}$ Or at the very least, Sen would have to account for how different groups may express different beliefs for what it means to be impartial and how this fits with his notion of the kind of impartial judgement that should preside over these diverse beliefs in public debate.

If there are many ways in which ethical orders determine how an action and its consequences can be evaluated under a conception of responsibility, ${ }^{83}$ then basic to these ways is imputability and how a self situated within his or her ethical order is held accountable according to what is esteemed or valued in terms of good and bad actions. By virtue of an ethical order, one sees oneself as imputable according to these standards. "[E]thico-moral predicates," as Ricoeur says,

allow us to judge and evaluate the actions considered good or bad, permitted or prohibited. When these predicates are applied reflexively to the agents themselves, these agents are said to be capable of imputation. ${ }^{84}$

Because imputability is self-reflexive in view of ethical concerns, it designates one of the highest forms of "self-reference" through which events and actions come under consideration and deliberation. ${ }^{85}$ This has the more local effect of integrating oneself 
within one's community since it allows one to be placed under the aegis of the authority of the community's ethical order. Ricoeur writes,

To be capable of entering into $a[n][\ldots]$ order is to be capable of entering into an order of recognition, of inscribing oneself in a "we" that distributes and apportions the authority of the $[\ldots]$ order. ${ }^{86}$

And elsewhere:

Practices ... are cooperative activities whose constitutive rules are established socially; the standards of excellence that correspond to them on the level of this or that practice originate much further back than the solitary practitioner. ${ }^{87}$

And because ethical actions by their very nature affect others, there is a demand placed on self-imputation to recognize the ethical standing of others beyond one's community. ${ }^{88}$

More globally, then, the self-reflexive nature of imputation allows one to extend one's ethical gaze towards difference. But this, of course, is not guaranteed. Ricoeur therefore emphasizes the deliberative aspect of ethical decision making (phronesis). $\mathrm{He}$ adds that imputation allows an individual's sense of care for the other to be articulated as the "internalized voice" of practical deliberation which draws upon the resources of an ethical order when attempting to choose well in view of others. "[T]he search for the 
choice appropriate to the situation," he comments, "is to recognize oneself as being enjoined to live well with and for others." 89 It is in deliberation that the voice of authority ascribed to one's ethical order is internalized in terms of one's own thought. The given authority is scrutinized through one's deliberation in a given situation of conflict. Indeed, to the voice of authority, the internalized voice of deliberation can present the exception to the rule.

Given the important role of imputation, the normative significance of impartiality can be expressed in more detail: In situations calling for impartiality, one's selfimputation as the deliberator who should be impartial involves the recognition that the others concerned are esteemed by oneself as being worthy of impartial judgement. Impartiality must be won through deliberation, or what Ricoeur describes as the "heroic" and "moral effort" to accommodate the other "against the backdrop of a shared understanding." 90

With this recovery of impartiality through the normative framework, Ricoeur subsequently redescribes the kind of distance that impartial judgement is supposed to provide. While conventionally we tend to view this distance in terms of neutrality or objectivity, Ricoeur frames it in terms of a "just distance" that allows for communication. Or if we wish to play with the meaning of the word "distance," one can say that the estimation of worthiness of the other involved in impartiality allows the initial distance in communication to become a "just distance" where convictions can be expressed. Because the other is worthy of impartial judgement, his or her case can be heard.

Ricoeur's account clearly moves beyond the aim of shared reasons since it asks conflicting parties to enter and understand a rival tradition with which they are engaged. 
It may be true that many instances of debate in the realm of distributive justice may not require this depth of engagement, but it is also true that some of the most problematic conflicts involve discussion in which both parties assume a sameness, identity, or simple commensurability between the languages through which each party articulates their view. Ricoeur, in this respect, uses tragic situations as the barometer for his theory, insisting that tragic situations of conflict require this deep level of engagement and that therefore a theory of justice should look towards its most volatile and problematic instances in offering a possible process of fair resolution. ${ }^{91}$

To be sure, a thorough account of what Ricoeur sees entailed in shared understanding would require an analysis of his account of mutual recognition and perhaps his discussion of memory and forgiveness. ${ }^{92}$ But with respect to the aim of this article, it is sufficient to refer to two examples that demonstrate how a shared understanding requires a thorough immersion in that person's order and system of thinking.

First example: Though not an instance of a direct conflict between ethical orders and individuals (but an indirect one at the level of economic goods), the philosopher and economist Philip Mirowski has pointed out with respect to economic theory that the metaphors it uses to explain and represent its subject of analysis determine the way in which its various research programs will envisage and represent disciplinary limitations and aims-most notably for Mirowski are the metaphors used to explain physical conservation principles (e.g., substance and field theories) ${ }^{93}$ Gaining perspective on this phenomenon requires entering into systematic concepts and structures in order to understand what may have constituted something like a break or shift in theoretical 
assumptions—e.g., why something like "equilibrium" can be deemed a good when it is a practical fiction. Such questions arise because some metaphors and concepts no longer work when attempting to explain economic phenomena. Understanding why this is so involves, on Mirowski's account, not just offering an alternative theory or assessing reasons but seeing how the problem arose through a historical development of thought. So one is asked to immerse oneself in an unfamiliar historical situation (or what is essentially the "other") in which such metaphors and concepts were posited. ${ }^{94}$ This approach can be said to result in a shared understanding because the inquirer has entered into a specific theoretical system in order to view its commitments and reasoning 'as if' in the first person. It does not entertain a simple notion of historical progress but one in which understanding the present and future requires engaging with the past, and indeed becoming aware of how a present view may be dominated by different metaphors.

Second example: Maclntyre has provided a formulation of the ways in which traditions can break out beyond parochial confines through a nuanced process of debate. It involves more than a simple consideration of compelling reasons offered from other "rival traditions" because each tradition must find a way to accommodate challenges by internally revising its current structures, practices, and concepts. ${ }^{95}$ Like Ricoeur, Maclntyre sees the translation and interpretation of traditional historical texts as central to the project of a tradition's revivification and ability to address changing historical circumstances. One of Maclntyre's more convincing instances with reference to moral traditions in philosophy concerns the comparison of the various attempts to translate the episode of Achilles' rage in The Iliad (I.189-192) where Achilles is 
conflicted when having to choose whether or not to strike down Agamemnon. Maclntyre points out that various translators use their own moral precepts to make sense of the conflict-i.e., between "rival thoughts" (George Chapman, 1598), "reason and passion" (Alexander Pope, 1715), and "alternating impulses of passion" (Robert Fitzgerald, 1974). ${ }^{96}$ For Maclntyre, this heterogeneity of translations produces a productive rivalry between moral traditions that ideally enables one to reinterpret ethical precepts by virtue of confronting outside challenges. This is not to forget, as mentioned earlier, that the adherents to a tradition must be willing to do so.

In both the works of Mirowski and Maclntyre, one finds a deliberate and laborious engagement with the historical development of concepts and theories in order to offer a way of revising current methods of inquiry. They see this not as superfluous to an understanding of their respective fields but necessary. ${ }^{97}$ In this respect, their historical concerns are not really a foray into historical details and contexts as much as they are a way of understanding how our current predicaments and impasses have emerged. These two examples, I am saying, help us to better envisage what may be required of shared understanding when engaging in public debate, especially since convictions, as shown earlier, are historically constituted.

\section{Conclusion}

The starting point of this article was the question concerning whether or not shared reasons are enough when conceiving the aim of impartiality. Sen's practical, comparative approach avers that such reasons can be discovered through a process of public, reasoned debate and the inclusion of an external impartial observer. My 
challenge to this thesis was staked on Ricoeur's analysis of convictions and how they run deeper than their correlative reasons or justifications may indicate. Simply countering one reason with another, more sufficient one in the process of debate does not address the ways in which convictions operate historically and culturally. A consensus of reasons, or shared reasons, is therefore not enough for a theory of distributive justice which aims to provide resolutions for conflicts. Instead, a more hospitable route that engages with another's ethical order or tradition is required so that a competing party or external observer can understand the complexities by which specific beliefs are seen as authoritative. Ricoeur refers to this as a shared understanding, shared because one has attempted to occupy a first-person position within the unfamiliar tradition. The implication of this is that a strategy for practical resolution is more complex and laborious than we might otherwise hope. But a truncated, pragmatic alternative seems much more dangerous insofar as we might create an illusion by which we think that we can represent another's convictions and ethical order by a meta- or neutral language.

This article was originally presented as a paper at the "Reading Ricoeur Once Again" conference in Lisbon, Portugal (July 2010). I would like to thank Tom Angier, Eileen Brennan, Alexandre Christoyannopoulos, David Corfield, Fanny Forest, Valentin Gerlier, Simon Kirchin, Rajesh Sampath, Kenneth R. Westphal and the blind reviewers for their comments and suggestions. 
1 Benhabib (1986, 300). Reference to monological reason goes back to Habermas (1979, 90); cf. Friedman (1989, 649).

2 Young $(1990,106)$. Benhabib $(2002,111-112 ; 1999)$ is not dismissive of impartiality and sees it as a necessity in a multicultural world.

${ }^{3}$ Anderson $(2003,240)$.

${ }^{4}$ Anderson $(2003,240)$.

${ }^{5}$ Young $(1990,4-5)$.

${ }^{6}$ Sen does not use the phrase "shared reasons," though it is nonetheless implied in his idea of reasons that we cannot reasonably reject $(2009,196)$. Anderson $(2001,29)$ speaks of "reasons that we can share" when referring to Sen's criticism of preference and a common aim. She refers also to the phrase independently $(1996,550)$.

${ }^{7}$ Sen $(1997,747-749)$.

${ }^{8} \operatorname{Sen}(2002 b, 4)$.

${ }^{9}$ That is to say, they are prior to judgement or pre-judged. See Gadamer $(1976,9)$.

${ }^{10}$ Ricoeur $(2007,84)$.

11 For an extreme view on untranslatability, see Rancière (2010). One can contrast Rancière's radical position with that of more moderate philosophers, like Scheffler (2010), who endorse "reasons of partiality" with respect to certain limits within a local community but in view of questions of global justice. For a study on dissensus and Ricoeur, see Abel (2012).

12 This assumption varies by degrees and can change even within the work of one philosopher. For example, Barry (1995) takes seriously deep conflict in conceptions of the good. In one sense, he maintains that such conflict is rectifiable when groups 
progressively adopt different conceptions of justice-i.e., advantage, reciprocity, impartiality $(1995,28-51)$. Yet in another sense, he seems to suggest that these conflicts are not due to a difference in respective conceptions of the good but simply incorrigible convictions $(1995,79)$. While Barry's position on impartiality is not "derived from the concept of rationality" $(1995,121)$ in any hard sense, his conception of progression to impartial justice presupposes a conception of rationality which narrows the scope of what is deemed reasonable in a debate. Mendus's (2002) treatment of partiality employs a similar type of process, designating care as the lynchpin by which impartiality can be recognized. Yet even in the most difficult cases she examines, especially under "the normative question," communication of partial reasons is not problematic-indeed movement from partial to impartial considerations requires it. Scheffler's account of valuing as "a complex syndrome of dispositions" that is "highly abstract and limited" can nonetheless be articulated rationally in relation to personal projects and membership to a group (2010, 102-103).

${ }^{13}$ These categories are loosely indicative. As I will comment later, O'Neill has famously endorsed a version of public reasoning stemming from Kant (see below note 48). Gaus (2010) attempts to resolve evaluative pluralism through a Kantian coordination game. As noted above, Barry proposes a progression of reasoning through different types of justice.

${ }^{14}$ See, for example, Taylor (1994) on Quebec.

${ }^{15}$ On impartiality in the legal sphere, see Ricoeur $(2000,120)$. For impartiality in relation to distributive justice, see Ricoeur (2007, 88-89). 
${ }^{16}$ Sen $(2009,49)$ refers to "reasoned scrutiny," and I am assuming this to be the same as his reference to critical scrutiny in, for example, Sen (2002b). Because The Idea of Justice reformulates much of Sen's earlier thinking in a more general format, when appropriate, I will often provide references to his articles that deal with the related subject matter in more detail.

17 Sen (2009, 139; 2002a, 445; cf. 2002b, 19-22).

18 Sen $(2009,10,15)$. Freeman takes issue with these claims, especially in relation to John Rawls (see below note 49).

${ }^{19} \operatorname{Sen}(2009,102-111 ; 2006,234-236)$.

${ }^{20}$ Anderson $(2003,251)$.

${ }^{21}$ Sen (1993b, 129; cf. 2009, 156).

22 Sen (2009, 157; cf. 1993b, 126-145).

${ }^{23} \operatorname{Sen}(1993 b, 129)$.

${ }^{24}$ Sen (1993b, 130).

${ }^{25} \operatorname{Sen}(1993 b, 131)$.

${ }^{26} \operatorname{Sen}(2002 a, 447-448)$.

27 Sen $(2009,44-46,124-126)$.

${ }^{28} \operatorname{Sen}(2009,169)$.

${ }^{29} \operatorname{Sen}(2009,156)$.

30 Sen $(2009,196)$.

${ }^{31}$ Friedman $(1989,649)$. For example, Sen $(2009,118)$ assumes that reasons should already include a degree of communicability and acceptability.

32 Ricoeur (2007, 89); cf. O’Neill (1996, 56-59). 
${ }^{33}$ This position is consistent with Sen's well-known defence of incomplete orderings in order to assess the well-being of economic agents $(2002 a, 456,468)$. For his discussion of this in relation to economics, see Sen $(1988,65-68)$. See also his response to Martha Nussbaum, in Sen (1993a, 47).

${ }^{34}$ See, for example, Sen's account of religious tolerance (2009, 36-39, 353-354); cf. Anderson $(2003,244)$.

${ }^{35} \operatorname{Sen}(1990,112,120)$.

${ }^{36}$ Ricoeur $(1998,56)$ as quoted in Kaplan $(2003,158)$.

${ }^{37}$ Anderson (2003, 257-258; emphasis in original).

38 Sen (2009, 140-145; 2006, 234-235); cf. Anderson (1996, 548-549).

39 See, for example, Maclntyre et al $(1969,31-55)$ on the history of philosophy in relation to the debate between theism and atheism where, as he describes it, the modern predicament is one where both sides of the debate are entirely unfamiliar with the status of moral vocabulary and the implicit and explicit claims it makes on a universal conception of human nature. As Gaus observes of Sen, "It is, I think, revealing that nowhere in The Idea of Justice do we confront a serious discussion of religious perspectives, and the nature of a religious person's social world" $(2012,271)$.

40 Sen $(1973,1997)$.

${ }^{41} \operatorname{Sen}(2005,8-12)$.

42 Sen $(1973,241)$.

${ }^{43} \operatorname{Sen}(1973,252-253)$. The quotation in brackets is taken from Sen $(1973,258)$.

${ }^{44} \operatorname{Sen}(2002 b, 25,40)$. 
45 Sen $(2009,119)$, quoting Gramsci $(1975,324)$. See also Sen $(2003,1242,1244-$ 1245).

${ }^{46} \operatorname{Sen}(2002 b, 43)$.

47 Sen (2009, 180; cf. 2002b, 41).

${ }^{48}$ Sen $(2009,120)$; cf. Sen (1993b, 138-139) on cultural relativism. O’Neill $(2010,388)$ criticizes Sen on this same point. She is reluctant to give up standards by which we can say some reasons are better than others, a move which, for Sen, would hint too much of ideal standards. O'Neill's (1986) alternative consists of Kant's conceptions of toleration and public reasoning. She is more optimistic about the process of public reasoning by which private points of view can be communicated. This is because some degree of a capacity to reason is presupposed by the attempt to engage in discussion. She recasts Kant's emphasis on a gradual process in which standards of reason emerge (1986, $537)$ as adequate for dealing with "the whirlpools of relativism" $(1986,539)$. While I am not in total disagreement with O'Neill's clarification of the processual nature of public reasoning, as I will argue this emphasis ignores those convictions a group might hold that cannot be translated into a public discourse due to radically different conceptions of ethical relation or what is of ultimate concern. O'Neill's account becomes inflexible on this view since the failure to communicate implies some degree of irrationality and further denigrates the group in question. This problem is evinced to some degree in O'Neill's (2009) analysis of the freedom of self-expression which, while rightfully criticizing claims that this freedom is unconditional, assumes that forms of incoherent self-expression lack a form of reasoning. 
${ }^{49}$ Sen $(2009,119)$. Despite Sen's critical orientation towards ideal conceptions, there is, as Freeman $(2012,189)$ points out, a kind of ideal society of "sincere and conscientious deliberators with moral sensibilities" who are capable and willing to listen. It should be noted that Freeman does not see Sen's position as contradictory, though perhaps weakened somewhat, because the assumptions of an ideal society implicit in Sen's theory do not "define" justice (as they do for Rawls) but help us to "discover" it (2012, 192).

50 See, respectively, Ricoeur (1991, 303-319; 1981, 308-324).

${ }^{51}$ For more on this in terms of personal points of view, see Thomas $(2005,34)$.

52 For an analysis of this, see Mei (2011).

53 See, for instance, Tideman $(1982,109-111)$. On the conventional nature of property and taxation, see Murphy et al $(2002,8)$.

54 On cultural instances relating to ethical frameworks and the determination of land use, see Bourdieu (1977, 60-61, 175).

${ }^{55}$ As Thomas comments, "The personal point of view functions as a transcendental condition for the availability of these reasons and not as an indexical parameter within them" $(2005,32)$.

56 See, for instance, the debates between Malthus and Ricardo as presented in Mei (2011, 313-315).

${ }^{57}$ Kenaan $(2002,123-124,126)$.

${ }^{58} \operatorname{Sen}(2009,191-192 ; 2005)$.

59 Hausman (2005) and Petit (2005).

${ }^{60}$ Ricoeur $(2000,54)$. 
${ }^{61}$ In relation to Rawls, see Ricoeur $(2000,66)$.

62 Ricoeur $(1992,21-22 ; 2007,66,75)$ says this about attestation. I take liberty in assuming the connection between attestation and convictions wherein convictions require attestation. See, for instance, Kaplan $(2003,124)$.

63 Ricoeur does not use the phrase "totality of signification," which is an English rendering of Heidegger's Bedeutungsganze in Being and Time (1962, 204/161). I have taken liberty here in joining Ricoeur's acceptance of Heidegger's concept of In-der-weltsein, to which Bedeutungsganze is related, and Ricoeur's reference to "symbolic orders" as systems in which ethical and moral precepts are figured.

64 Ricoeur $(2007,84)$. I have omitted the word "symbolic" from the passage since I wanted to isolate a part of Ricoeur's argument without going into the nature of symbolic orders which is beyond the remit of this article. For Maclntyre on order, see (1988, 379; 2006b, 205-206).

65 Sen $(2009,50)$. Cf. Maclntyre (2006a, 177).

66 Ricoeur $(1992,22)$. He says this about attestation, but it is plain that attestation constitutes the foundation for ethical reasoning with respect to capability and imputability.

67 Maclntyre (1988, 352-369).

68 Ricoeur (2007, 247; 1992, 289). On universalization and argumentation in Ricoeur, see Kaplan (2003, 118-124).

${ }^{69}$ Ricoeur (1986, 312).

${ }^{70}$ Ricoeur $(1981,212)$.

${ }^{71}$ Ricoeur (2007, 232-248). 
72 Bourdieu (1977, 196).

${ }^{73}$ Ricoeur (2005) reads recognition and respect quite discreetly in terms of recognizing another to be like oneself, not simply as a way of tolerating the other in order to debate. Granting respect would in this sense mean knowing that despite some substantial difference, the other person is respectable by virtue of being like oneself according to whatever predicate it may involve.

${ }^{74}$ Ricoeur $(2007,246)$. On translation, see Ricoeur (2006, especially chapter 2).

${ }^{75}$ Ricoeur (1992, 289).

${ }^{76}$ Ricoeur $(2000,57)$.

77 Ricoeur (2007, 89).

${ }^{78}$ See, for instance, his debate with Hans Kung on a global ethic in Ricouer (1996).

79 This becomes especially clear in F. M. Kamm's (2011) account of duties between internal and external groups in relation to Sen's conception of open impartiality.

${ }^{80}$ Ricoeur $(2007,88)$. Ricoeur quotes from Thomas Nagel. Though he relies on Nagel's discussion of impartiality, he sees its limitation as a lack of concern for mutuality.

${ }^{81}$ Ricoeur (2007, 47; cf. 64-65). Ricoeur elaborates the Kantian notion of imputability from the "Third Cosmological Antinomy" in the Critique of Pure Reason.

82 Sen $(2000,477-479 ; 482)$.

${ }^{83}$ See Williams $(2008,55)$.

${ }^{84}$ Ricoeur $(2005,105-106)$.

${ }^{85}$ Ricoeur $(2005,106 ; 2007,47)$.

${ }^{86}$ Ricoeur $(2007,88)$. I omit the word "symbolic" where the ellipses appear.

${ }^{87}$ Ricoeur $(1992,176)$. 
88 O'Neill (1996, 100).

${ }^{89}$ Ricoeur (1992, 352; italics omitted).

90 Ricoeur $(2007,89)$. Pellauer $(2012,61)$ therefore sees Ricoeur's notion of linguistic hospitality becoming more a "moral hospitality" in relation to a conception of the just.

${ }^{91}$ Kaplan $(2003,122)$ and Abel (2012).

92 See, Ricoeur (2004).

${ }^{93}$ Mirowski (1989).

${ }^{94}$ Cf. Collingwood (1940, 34-57).

95 Maclntyre (1988, 370-388). Historical examples of this include the so-called periods of secularization during the $18^{\text {th }}$ and $19^{\text {th }}$ centuries for Christianity and Judaism where orthodoxy was faced with questions of accommodating state law and statutes.

96 Maclntyre $(1988,17)$.

${ }^{97}$ See, for example, Maclntyre (1984, 269) and Mirowski (1989, 7-8).

\section{Bibliography}

Abel, Olivier

2012 "The Unsurpassable Dissensus: The Ethics of Forgiveness in Paul Ricoeur's Work," in From Ricoeur to Action: The Significance of Ricoeur's Socio-Political Thinking, Todd Mei and David Lewin, eds., 211-228. London: Continuum.

Anderson, Elizabeth 
2003 "Sen, Ethics, and Democracy," Feminist Economics 9 (2-3), 239261.

2001 'Unstrapping the Straitjacket of 'Preference': A Comment on Amartya Sen's Contributions to Philosophy and Economics," Economics and Philosophy 17, 21-38.

1996 "Reasons, Attitudes, and Values: Replies to Sturgeon and Piper," Ethics 106:3, 538-554.

Barry, Brian

1995 Justice as Impartiality. Oxford: Oxford University Press.

Benhabib, Seyla

2002 The Claims of Culture: Equality and Diversity in the Global Era. Princeton: Princeton University Press.

1999 "The Liberal Imagination and the Four Dogmas of Multiculturalism," The Yale Journal of Criticism 12:2, 401-413.

1986 Critique, Norm, and Utopia. New York: Columbia University Press.

Bourdieu, Pierre

1977 Outline of a Theory of Practice, Richard Nice, trans. Cambridge: Cambridge University Press.

Collingwood, R. G.

1940 An Essay on Metaphysics. Oxford: Clarendon Press.

Freeman, Samuel

2012 "Ideal Theory and the Justice of Institutions vs. Comprehensive Outcomes," Rutgers Law Journal 43:2, 169-209. 
Friedman, Marilyn

1989 "The Impracticality of Impartiality," The Journal of Philosophy 86:11, 645-656.

Gadamer, Hans-Georg

1976 Philosophical Hermeneutics. Berkeley: University of California Press.

Gaus, Gerald

2012 "Social Contract and Social Choice," Rutgers Law Journal 43, 243276.

2010 "The Demands of Impartiality and the Evolution of Morality," in Partiality and Impartiality: Morality, Special Relationships, and the Wider World, Brian Feltham and John Cottingham, eds., 41-64. New York: Oxford University Press.

Gramsci, Antonio

1975 Letters from Prison, Lynne Lawner, trans. London: Jonathan Cape.

Habermas, Jürgen

1979 Communication and the Evolution of Society, Thomas McCarthy, trans. London: Heinemann.

Hausman, Daniel

2005 "Sympathy, Commitment, and Preference," Economics and Philosophy 21, 33-50.

Heidegger, Martin 
1962 Being and Time, John Macquarrie and Edward Robinson, trans. Oxford: Blackwell.

Kamm, F. M.

2011 "Sen on Justice and Rights: A Review Essay," Philosophy and Public Affairs 39:1, 99-103.

Kaplan, David

2003 Ricoeur's Critical Theory. Albany: SUNY Press.

Kenaan, Hagi

2002 "Language, philosophy and the risk of failure: rereading the debate between Searle and Derrida," Continental Philosophy Review 35, 117-133.

MacIntyre, Alasdair

2006a Ethics and Politics: Selected Essays, Volume 2. Cambridge: Cambridge University Press.

2006b Tasks of Philosophy: Selected Essays, Volume 1. Cambridge: Cambridge University Press.

1988 Whose Justice? Which Rationality? Notre Dame: University of Notre Dame Press.

1984 After Virtue, Second Edition. Notre Dame: University of Notre Dame Press.

Maclntyre, Alasdair and Paul Ricoeur

1969 The Religious Significance of Atheism. New York: Columbia University Press. 
Mei, Todd

2011 "An Economic Turn: A Hermeneutical Reinterpretation of Political Economy with Respect to the Question of Land," Research in Phenomenology 41, 297-326.

Mendus, Susan

2002 Impartiality in Moral and Political Philosophy. Oxford: Oxford University Press.

Mirowski, Philip

1989 More Heat than Light: Economics as Social Physics, Physics as Nature's Economics. Cambridge: Cambridge University Press.

Murphy, Liam and Thomas Nagel

2002 The Myth of Ownership: Taxes and Justice. Oxford: Oxford University Press.

O’Neill, Onora

2010 "Amartya Sen: The Idea of Justice," The Journal of Philosophy 107:7, 384-388.

2009 "Ethics for Communication?" European Journal of Philosophy 17:2, $167-180$.

1996 Towards Justice and Virtue: A Constructive Account of Practical Reasoning. Cambridge: Cambridge University Press.

1986 "The Public Use of Reason," Political Theory 14:4, 523-551.

Pellauer, David 
2012 "Looking for the Just," in Paul Ricoeur and the Task of Political Philosophy, Greg S. Johnson and Dan R. Stiver, eds., 51-63, Lanham: Lexington Books.

Petit, Philip

2005 "Construing Sen on Commitment," Economics and Philosophy 21, 15-32.

Rancière, Jacques

2010 Dissensus: On Politics and Aesthetics, Steven Corcoran, trans. London: Continuum.

Ricoeur, Paul

2007 Reflections on the Just, David Pellauer, trans. Chicago: University of Chicago Press.

2006 On Translation, Eileen Brennan, trans. London: Routledge.

2005 The Course of Recognition, David Pellauer, trans. Cambridge: Harvard University Press.

2004 Memory, History, Forgetting, Kathleen Blamey and David Pellauer, trans. Chicago: University of Chicago Press.

2000 The Just, David Pellauer, trans. Chicago: University of Chicago Press, 2000.

1998 Critique and Conviction, Kathleen Blamey, trans. Chicago: University of Chicago Press.

1996 "Entretien Hans Kung - Paul Ricouer: autour du 'Manifeste pour une éthique planétaire"; available at 
http://www.fondsricoeur.fr/photo/Entretien\%20Hans\%20KUNG\%20-

\%20Paul\%20RICOEUR\%20V2.pdf, accessed September 12, 2013.

1992 Oneself as Another, Kathleen Blamey, trans. Chicago: University of Chicago Press.

1991 A Ricoeur Reader: Reflection and Imagination, Mario J. Valdés, ed. New York: Harvester Wheatsheaf.

1981 From Text to Action: Essays in Hermeneutics, Volume II. Evanston: Northwestern University Press.

1986 Lectures on Ideology and Utopia, George H. Taylor, ed. New York: Columbia University Press.

Scheffler, Samuel

2010 "Morality and Reasonable Partiality," in Partiality and Impartiality: Morality, Special Relationships, and the Wider World, Brian Feltham and John Cottingham, eds., 98-130. New York: Oxford University Press.

Sen, Amartya

2009 The Idea of Justice. Cambridge: The Belknap Press of Harvard University.

2006 "What Do We Want from a Theory of Justice?" The Journal of Philosophy 103:5, 215-238.

2005 "Why Exactly Is Commitment Important for Rationality," Economics and Philosophy 1, 5-14. 
2003 "Sraffa, Wittgenstein, and Gramsci," Journal of Economic Literature $41,1240-1255$.

2002a "Open and Closed Impartiality," The Journal of Philosophy 99:9, 445-469.

2002b Rationality and Freedom. Cambridge: The Belknap Press of Harvard University.

2000 "Consequential Evaluation and Practical Reason," The Journal of Philosophy 97:9, 477-502.

1998 On Ethics and Economics. Oxford: Blackwell.

1997 "Maximization and the Act of Choice," Econometrica 65:4, 745-779.

1993a "Capability and Well Being," in The Quality of Life, Martha C. Nussbaum and Amartya Sen, eds., 30-53. Oxford: Clarendon Press.

1993b "Positional Objectivity," Philosophy and Public Affairs 22:2, 126145.

1990 “Justice: Means versus Freedoms," Philosophy and Public Affairs 19:2, 111-121.

1973 "Behaviour and the Concept of Preference," Economica 40:159, 241-259.

Taylor, Charles

1994 "The Politics of Recognition," in Multiculturalism, Amy Gutmann, ed., 25-73. Princeton: Princeton University Press.

Tideman, Nicolaus 
1982 "A Tax on Land Value Is Neutral," National Tax Journal 35:1, 190111.

Thomas, Alan,

2005 "Reasonable Partiality and the Agent's Point of View," Ethical Theory and Moral Practice 8, 25-43.

Williams, Bernard

2008 Shame and Necessity. Berkeley: University of California Press.

Young, Iris.

1990 Justice and the Politics of Difference. Princeton: Princeton University Press. 